\title{
Effects of aloe polysaccharide, a polysaccharide extracted from Aloe vera, on TNF- $\alpha$-induced HaCaT cell proliferation and the underlying mechanism in psoriasis
}

\author{
HONG LENG* , LI PU*, LONGJIANG XU, XIN SHI, JIANG JI and KUN CHEN \\ Dermatological Department, Jiangsu Provincial Key Laboratory of Molecular Biology for Skin Disease and STIs, \\ The Second Affiliated Hospital of Soochow University, Nanjing, Jiangsu 210042, P.R. China
}

Received February 5, 2017; Accepted June 14, 2018

DOI: $10.3892 / \mathrm{mmr} .2018 .9319$

\begin{abstract}
Aloe vera is a traditional wound-healing medicine used for the treatment of skin disorders. Aloe polysaccharide (APS) is the main macromolecule of Aloe vera, which contributes to its function. Psoriasis is an immune-mediated chronic inflammatory disease, which affects $2-3 \%$ of the general population. The conventional remedies used to treat psoriasis demonstrate limited effects; therefore, natural products, including Aloe vera, are being taken into consideration. However, the effects of APS on the treatment of psoriasis and the underlying mechanisms remain to be elucidated. The human keratinocyte cell line HaCaT was used to determine the effects of APS on psoriasis. Cells were randomly divided into five groups: i) Negative control group; ii) tumor necrosis factor (TNF)- $\alpha$ stimulated psoriasis model group; and iii) APS (20, 40 and $80 \mu \mathrm{g} / \mathrm{ml})$ pretreated psoriasis groups. Cell viability and proliferation were investigated using the CCK-8 assay. ELISA and western blotting were applied to study the abundance of interleukin (IL)- 8 and IL-12 in TNF- $\alpha$-incubated culture medium and APS-treated $\mathrm{HaCaT}$ cells, respectively. In addition, the mRNA expression levels of p65, and the protein expression levels of nuclear factor (NF)- $\kappa \mathrm{B}$ inhibitor- $\alpha(\mathrm{I} \kappa \mathrm{B} \alpha)$ and phosphorylated-p65, were detected by reverse transcription-quantitative polymerase chain reaction and western blotting, respectively. APS was revealed to significantly reduce TNF- $\alpha$-stimulated elevation of $\mathrm{HaCaT}$ cell proliferation in a dose-dependent manner. The expression levels of inflammatory factors, including IL-8 and IL-12, were increased in response to
\end{abstract}

Correspondence to: Dr Kun Chen, Dermatological Department, Jiangsu Provincial Key Laboratory of Molecular Biology for Skin Disease and STIs, The Second Affiliated Hospital of Soochow University, 12 Jiangwangmiao Street, Nanjing, Jiangsu 210042, P.R. China

E-mail: chenkunszu@126.com

*Contributed equally

Key words: aloe polysaccharide, psoriasis, inflammation, nuclear factor- $\kappa \mathrm{B}$ signaling pathway
TNF- $\alpha$. In addition, the mRNA and protein expression levels of p65 were increased following treatment with TNF- $\alpha$. Notably, treatment with APS was demonstrated to significantly attenuate the aforementioned effects in a dose-dependent manner. Furthermore, Iк $\mathrm{B} \alpha$ protein expression levels were significantly reduced following treatment with $\mathrm{TNF}-\alpha$, which was significantly reversed following treatment with APS. In conclusion, these results suggested that APS inhibited TNF- $\alpha$-induced proliferation of keratinocytes and overactivation of the $\mathrm{NF}-\kappa \mathrm{B}$ signaling pathway.

\section{Introduction}

Psoriasis is a chronic inflammatory autoimmune disease that predominantly affects the skin (1). The pathogenesis of psoriasis is complex, and involves genetic, immunological and environmental factors (2). The development of the disease is characterized by continuous relapses. In addition, patients with psoriasis tend to suffer from the disease for their entire lives (3). At present, psoriasis is incurable; however, it may be controlled with medication. Topical corticosteroid agents are the most effective therapeutic approach for the treatment of this disease. Treatment with systemic therapies, including numerous monoclonal antibodies and inhibitors, are often used to treat patients with psoriasis resistant to topical therapy or alternative therapies; however, the adverse side effects of systemic therapies including nausea, gastrointestinal intolerance, hyperlipidaemia should not be underestimated $(4,5)$. Considering this, phytomedicine has been considered as an alternative therapy for the treatment of patients with psoriasis, due to its safety and tolerability (6).

It is reported that the active ingredients of Aloe vera could be used as antibacterials and wound-healing promoters. Aloe polysaccharide (APS) is the main bioactive component of Aloe vera (7). Traditionally, Aloe vera has been used to treat patients with skin disorders. Numerous studies have revealed that Aloe vera exhibits anti-inflammatory and antioxidant effects $(8,9)$. Previous studies investigating whether Aloe vera exhibits therapeutic effects when administered to patients with psoriasis have generated mixed results $(10,11)$.

It has been well established that tumor necrosis factor (TNF)- $\alpha$ is involved in direct and indirect regulation of 
numerous genes involved in immune and inflammatory responses (12). In patients with psoriasis, the serum levels of TNF- $\alpha$ are associated with disease activity. During the development of psoriasis, TNF- $\alpha$ is secreted by $\mathrm{T}$ cells and has an important role in the pathogenic process (13). Despite previous studies suggesting that Aloe vera may represent a promising therapeutic agent for the treatment of patients with psoriasis $(6,14,15)$. To the best of our knowledge, the molecular mechanism underlying the involvement of TNF- $\alpha$ and APS in treatment of psoriasis has not yet been investigated.

Nuclear factor (NF)- $\kappa \mathrm{B}$ has an important role in inflammation via induction of the transcription of proinflammatory genes (16). Members of the NF- $\kappa \mathrm{B} /$ Rel family include $\mathrm{NF}-\kappa \mathrm{B} 1$ (p50/p105), NF-кB2 (p52/p100), p65 (RelA), RelB and c-Rel. p65 can form active heterodimers with a p50 or p52 subunit containing transactivation domains (17). In its inactive form, $\mathrm{NF}-\kappa \mathrm{B}$ is sequestered in the cytoplasm associated with $\mathrm{I} \kappa \mathrm{B}$. Upon stimulation, I $\mathrm{B}$ is degraded, which then triggers phosphorylation of p65 (18). A previous study revealed that there is a significant overexpression of phosphorylated (p)-p65 in the epidermis of psoriatic plaques compared with normal skin (19). Furthermore, it has been demonstrated that Aloe vera can directly inhibit $\mathrm{NF}-\kappa \mathrm{B}$ activation in peripheral blood mononuclear cells (20); however, whether APS can alleviate the symptoms of psoriasis via inactivation of $N F-\kappa B$ is largely unknown. The study was designed to examine whether APS inhibited TNF- $\alpha$-induced proliferation of keratinocytes through $\mathrm{NF}-\kappa \mathrm{B}$ signaling pathway.

\section{Materials and methods}

Cell culture and agents. HaCaT cells (Shanghai Blowing Applied Biotechnology Co., Ltd., Shanghai, China; STR profile confirmed as appropriate) were cultured in Dulbecco's modified Eagle's medium supplemented with $10 \%$ fetal bovine serum, and $1 \%$ penicillin and streptomycin (Sigma-Aldrich; Merck KGaA, Darmstadt, Germany), and were incubated at $37^{\circ} \mathrm{C}$ in a humidified incubator containing $5 \% \mathrm{CO}_{2}$. Recombinant human TNF- $\alpha$ was purchased from BioLegend, Inc. (San Diego, CA, USA). APS (75.6\%) was supplied by the Chinese Academy of Sciences, Shanghai Institute of Materia Medica (Shanghai, China).

Cell viability assay. The viability of $\mathrm{HaCaT}$ cells was investigated using Cell Counting Kit-8 (CCK-8; Dojindo Molecular Technologies, Inc., Kumamoto, Japan). Cells were seeded into a 96 -well plate at a density of $5.0 \times 10^{3}$ cells/well and were incubated for $24 \mathrm{~h}$ at $37^{\circ} \mathrm{C}$ in $5 \% \mathrm{CO}_{2}$. Subsequently, cells were treated with TNF- $\alpha(10 \mathrm{ng} / \mathrm{ml})$, various concentrations of APS $(20-80 \mu \mathrm{g} / \mathrm{ml})$ or a combination of TNF- $\alpha(10 \mathrm{ng} / \mathrm{ml})$ and APS $(20,40$ and $80 \mu \mathrm{g} / \mathrm{ml})$ for $24 \mathrm{~h}$ at $37^{\circ} \mathrm{C}$ in $5 \% \mathrm{CO}_{2}$. CCK-8 solution $(10 \mu \mathrm{l})$ was then added to each well, and the plates were incubated for an additional $2 \mathrm{~h}$ at $37^{\circ} \mathrm{C}$. The control group was treated with an equal amount of PBS. Absorbance values at $450 \mathrm{~nm}$ were determined for each well using a microplate reader. Cell proliferation rate $=\left(\mathrm{OD}_{24 \mathrm{~h}}-\mathrm{OD}_{0 \mathrm{~h}}\right) / \mathrm{OD}_{0 \mathrm{~h}} \times 100 \%$. All assays were carried out in triplicate.

ELISA. HaCaT cells were treated with either TNF- $\alpha$ or a combination of TNF- $\alpha$ and various concentrations of
APS, and supernatants were collected $24 \mathrm{~h}$ post-treatment. Concentrations of interleukin (IL)-8 (cat. no. D8000C) and IL-12 (cat. no. M1270) were determined using ELISA kits (RayBiotech, Inc., Norcross, GA, USA). Briefly, $100 \mu \mathrm{l}$ of each standard and supernatant sample were added to a 96-well plate coated with anti-Human IL-8 or IL-12 and incubated overnight at $4^{\circ} \mathrm{C}$ with gentle agitation. Plates were subsequently washed four times with wash buffer. Wells were then incubated for $1 \mathrm{~h}$ with IL-8 or IL-12 specific biotinylated antibodies at room temperature, and were rinsed four times with wash buffer. Following this, cells were treated with diluted streptavidin solution (100 $\mu \mathrm{l} /$ well) for $45 \mathrm{~min}$ at room temperature, washed four times with wash buffer, and further incubated for $30 \mathrm{~min}$ at room temperature with $100 \mu 1 \mathrm{TMB}$ One-Step substrate reagent in the dark. The plates were quenched with stop solution and absorbance values were detected at $450 \mathrm{~nm}$ using a PowerWave XS spectrophotometer (BioTek Instruments, Inc., Winooski, VT, USA). ELISA analyses for each sample were repeated in triplicate. All assays were carried out in triplicate.

Western blotting. Protein lysates were prepared using radioimmunoprecipitation assay lysis buffer (Beyotime Institute of Biotechnology, Haimen, China) with a protease/phosphatase inhibitor cocktail (Cell Signaling Technology, Inc., Danvers, MA, USA). Antibodies for IL-8 (cat. no. 94853S; 1:1,000), $\mathrm{NF}-\kappa \mathrm{B}$ inhibitor- $\alpha(\mathrm{I} \kappa \mathrm{B} \alpha$; cat. no. $4814 \mathrm{~S} ; 1: 1,000), \mathrm{NF}-\kappa \mathrm{B}$ (p65; cat. no. 8242S; 1:1,000) purchased from Cell Signaling Technology, Inc, and IL-12 (cat. no. ab9992; 1:1,000) purchased from Abcam, (Cambridge, MA, USA). GAPDH mouse monoclonal antibody (cat. no. D190636; 1:1,000) was purchased from Sangon BioTech Co., Ltd. (Shanghai, China). The protein concentrations were determined through BCA Protein Assay kit (Vazyme, Piscataway, NJ, USA). Samples with equal amounts of protein $(25 \mu \mathrm{g})$ were fractionated on $10 \%$ SDS-PAGE and were then transferred to polyvinylidene fluoride membranes. Following blocking with 5\% non-fat milk for $1.5 \mathrm{~h}$ at $25^{\circ} \mathrm{C}$, the membranes were incubated with primary antibodies for at $4^{\circ} \mathrm{C}$ overnight. Membranes were then washed with PBS and incubated with goat anti Rabbit IgG horseradish peroxidase (cat. no. ab6721; 1:1,000) for another $2 \mathrm{~h}$ at $25^{\circ} \mathrm{C}$. Blots were developed with SuperSignal West Femto Maximum Sensitivity Substrate (Thermo Fisher Scientific, Inc., Waltham, MA, USA) and the images were obtained by ImageQuant LAS 4000 (GE Healthcare Life Sciences, Little Chalfont, UK). All assays were carried out in triplicate.

Reverse transcription-quantitative polymerase chain reaction $(R T-q P C R)$. Extraction of RNA from cell lysates was performed using an RNeasy kit (Qiagen $\mathrm{GmbH}$, Hilden, Germany). RNA was then subjected to cDNA synthesis using PrimeScript RT reagent kit (Takara Bio, Inc., Otsu, Japan). Synthesized cDNA was analyzed by RT-qPCR using SYBR Premix Ex Taq (Takara Bio, Inc.) according to manufacturer's protocol, the PCR conditions consisted of $95^{\circ} \mathrm{C}$ for $30 \mathrm{sec}$, followed by 40 cycles of amplification $\left(95^{\circ} \mathrm{C}\right.$ for $3 \mathrm{sec}$ and $60^{\circ} \mathrm{C}$ for $\left.30 \mathrm{sec}\right)$. Bio-Rad CFX96 Touch $^{\mathrm{TM}}$ Real-Time PCR Detection system (Bio-Rad Laboratories, Inc., Hercules, CA, USA) was performed. The fold-change was determined as $2^{-\Delta \Delta \mathrm{Cq}}$ using $\beta$-actin as an internal control (21). The primer sequences are as follows: NF- $\kappa$ B (p65), forward 5'-ATCAAT 


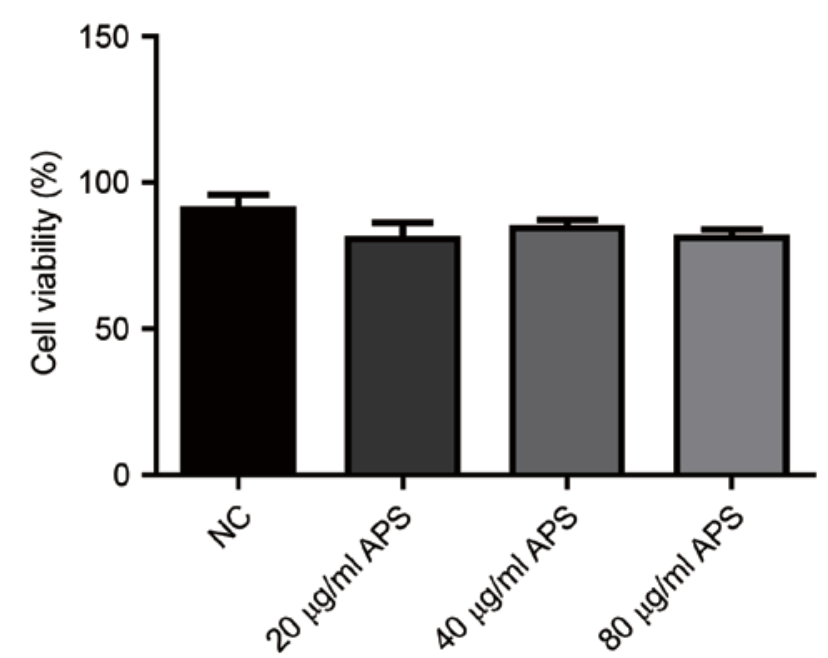

Figure 1. Treatment with APS has no marked effects on the viability of $\mathrm{HaCaT}$ keratinocytes. Compared with in the NC group, the viability of cells treated with various concentrations of APS $(20,40$ and $80 \mu \mathrm{g} / \mathrm{ml})$ was not significantly altered. APS, aloe polysaccharide; NC, negative control.

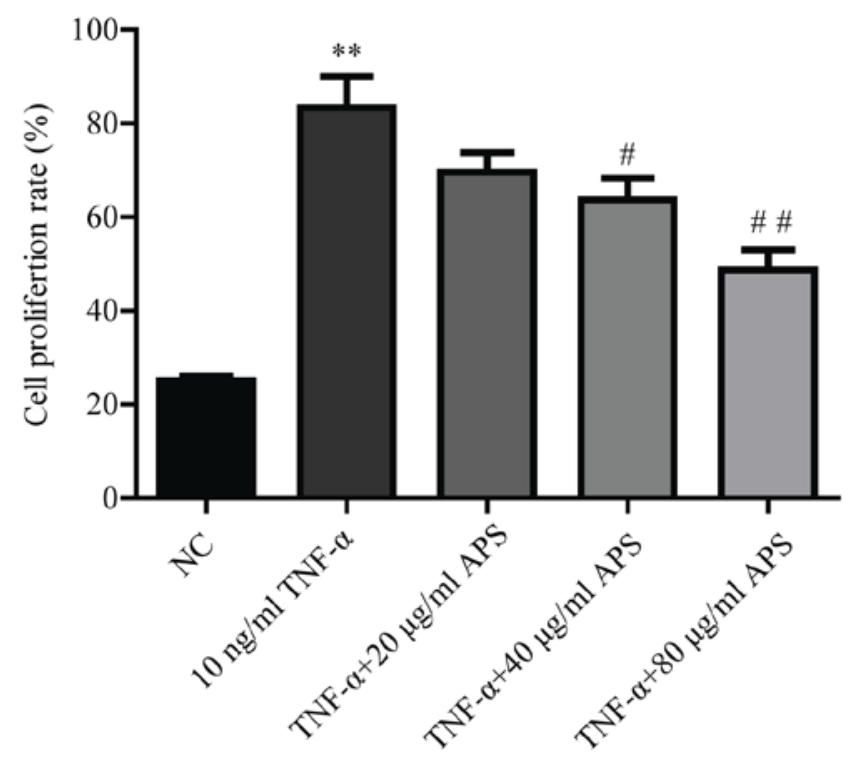

Figure 2. APS significantly inhibits TNF- $\alpha$-induced upregulation of $\mathrm{HaCaT}$ cell proliferation in a dose-dependent manner. Treatment with $10 \mathrm{ng} / \mathrm{ml} \mathrm{TNF}-\alpha$ significantly increased cell proliferation of $\mathrm{HaCaT}$ cells compared with in the NC group. In addition, treatment with APS (20, 40 and $80 \mu \mathrm{g} / \mathrm{ml}$ ) significantly decreased $\mathrm{TNF}-\alpha$-induced proliferation of $\mathrm{HaCaT}$ cells in a dose-dependent manner. ${ }^{* *} \mathrm{P}<0.01$ vs. $\mathrm{NC} ;{ }^{\#} \mathrm{P}<0.05$ and ${ }^{\# \#} \mathrm{P}<0.01$ vs. TNF- $\alpha$-treated group. APS, aloe polysaccharide; NC, negative control; TNF- $\alpha$, tumor necrosis factor- $\alpha$.

GGCTACACAGGA-3', reverse 5'-CCCGTGAAATACACC TCA-3'; and $\beta$-actin forward 5'-CATGTACGTTGCTATCCA GGC-3' and reverse 5'-CTCCTTAATGTCACGCACGAT-3'. All assays were carried out in triplicate.

Statistical analysis. All data were analyzed using Prism 5.0 software (GraphPad Software Inc., La Jolla, CA, USA) and expressed as the means \pm standard error of the mean. Significant differences between groups were statistically analyzed using one-way analysis of variance followed by the Newman-Keuls method. $\mathrm{P}<0.05$ was considered to indicate a statistically significant difference. All assays were carried out in triplicate in the present study.

\section{Results}

Treatment with APS has no marked effects on the viability of HaCaT keratinocytes. The viability of HaCaT cells was investigated to determine the effects of APS on HaCaT keratinocytes. The results demonstrated that compared with in the negative control (NC) group, cell viability was not altered following treatment with APS (20, 40 and $80 \mu \mathrm{g} / \mathrm{ml})$ (Fig. 1).

APS inhibits TNF- $\alpha$ induced proliferation of HaCaT keratinocytes. Psoriasis is characterized by excessive proliferation of keratinocytes $(14,15)$; therefore, the majority of treatment strategies to alleviate psoriasis are via suppression of the proliferation of keratinocytes. To investigate the effects of APS on psoriasis, HaCaT cells were treated with various concentrations of APS $(20,40$ and $80 \mu \mathrm{g} / \mathrm{ml})$ for 24 h. Furthermore, TNF- $\alpha$ is involved in the overproliferation of keratinocytes (22). The results of the present study demonstrated that HaCaT cells treated with $10 \mathrm{ng} / \mathrm{ml} \mathrm{TNF}-\alpha$ exhibited a significantly increased rate of cell proliferation compared with in the NC group (Fig. 2). In addition, the results revealed that TNF- $\alpha$-stimulated cells treated with APS exhibited significantly decreased rates of cell proliferation in a dose-dependent manner compared with cells treated with TNF- $\alpha$ alone (Fig. 2). These results suggested that APS inhibited the inflammatory factor-induced proliferation of $\mathrm{HaCaT}$ keratinocytes.

APS decreases TNF- $\alpha$-induced production of inflammatory factors. Inhibition of $\mathrm{TNF}-\alpha$ regulates numerous inflammatory factors; therefore, TNF- $\alpha$ inhibitors have been approved for the treatment of patients with psoriasis (23). Following treatment with $10 \mathrm{ng} / \mathrm{ml} \mathrm{TNF}-\alpha$, or a combination of $10 \mathrm{ng} / \mathrm{ml}$ TNF- $\alpha$ and increasing concentrations of APS (20, 40 and $80 \mu \mathrm{g} / \mathrm{ml}$ ), for $24 \mathrm{~h}, \mathrm{IL}-8$ and IL-12 protein expression levels were detected in $\mathrm{HaCaT}$ cell lysates. The results of western blotting revealed that TNF- $\alpha$ treatment significantly enhanced the protein expression levels of IL-8 and IL-12 compared with in the NC group (Fig. 3A-C). Furthermore, cells additionally treated with APS exhibited significantly decreased levels of IL-8 and IL-12 in a dose-dependent manner compared with in cells treated with TNF- $\alpha$ alone (Fig. 3A-C).

APS suppresses TNF- $\alpha$-induced secretion of inflammatory factors. Following treatment with TNF- $\alpha$, cells exhibited enhanced levels of secreted IL- 8 and IL-12 into the culture medium compared with in the NC group (Fig. 4A and B). In addition, in TNF- $\alpha$-stimulated cells treated with increasing concentrations of APS, the secretion of IL- 8 and IL-12 into the culture medium was significantly decreased in a dose-dependent manner compared with in cells treated with TNF- $\alpha$ alone (Fig. 4A and B).

APS suppresses TNF- $\alpha$-induced enhancement of p $65 \mathrm{mRNA}$ expression. $\mathrm{NF}-\kappa \mathrm{B}$ functions as a linker for dysregulated crosstalk between keratinocytes and immune cells in the pathogenesis of psoriasis (24). In patients with psoriasis, 
A

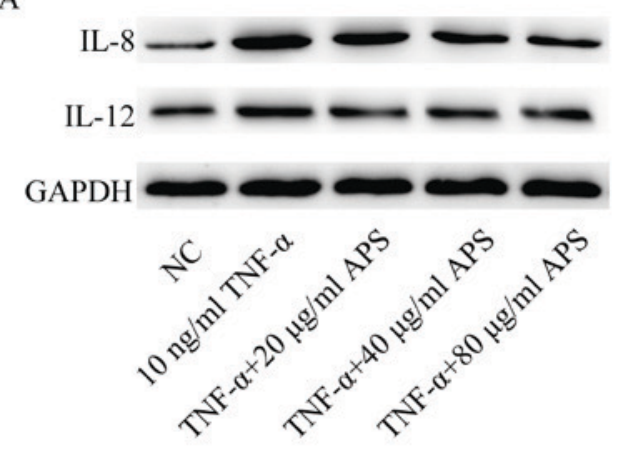

B

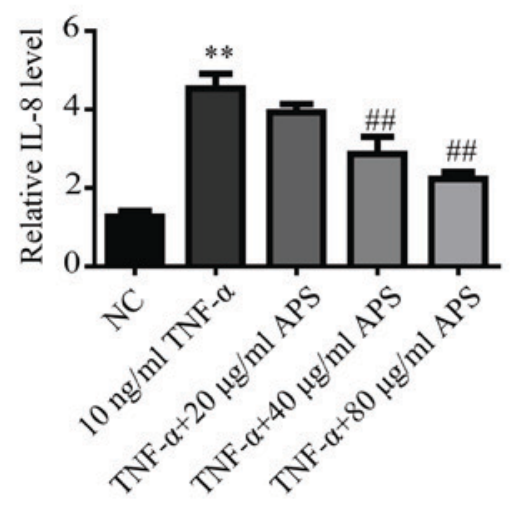

$\mathrm{C}$

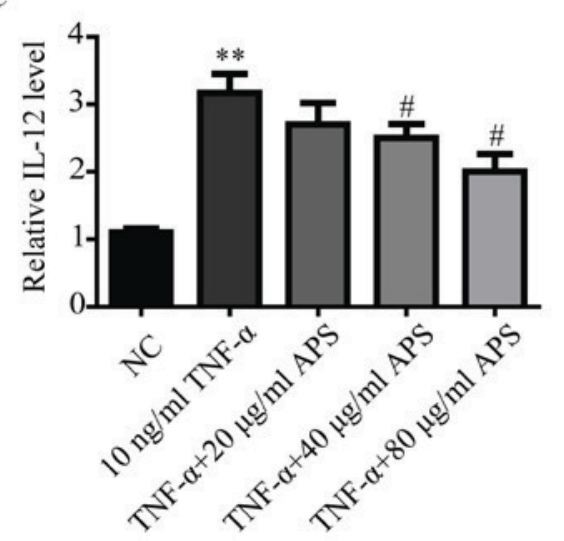

Figure 3. APS significantly suppresses TNF- $\alpha$-induced expression of IL- 8 and IL-12 in HaCaT cells in a dose-dependent manner. (A) Western blotting results revealed that the expression levels of IL-8 and IL-12 were increased following treatment with TNF- $\alpha$ and subsequently decreased following treatment with APS in a dose-dependent manner. Semi-quantitative analysis of (B) IL-8 and (C) IL-12 protein expression. ${ }^{* *} \mathrm{P}<0.01$ vs. NC; ${ }^{*} \mathrm{P}<0.05$ and ${ }^{\# \#} \mathrm{P}<0.01$ vs. TNF- $\alpha$-treated group. APS, aloe polysaccharide; IL, interleukin; $\mathrm{NC}$, negative control; TNF- $\alpha$, tumor necrosis factor- $\alpha$.

$\mathrm{NF}-\kappa \mathrm{B}$ signaling is normally activated by TNF- $\alpha$; therefore, TNF- $\alpha$ inhibitory drugs such as etanercept may decrease p-p65 levels and subsequently attenuate symptoms of the disease (25). Following treatment with TNF- $\alpha$, HaCaT cells exhibited increased expression levels of p65 mRNA compared with in the NC group; however; administration of APS attenuated this effect in a dose-dependent manner (Fig. 5).

APS downregulates TNF- $\alpha$-induced $N F-\kappa B$ activity. Notably, following treatment with TNF- $\alpha$, the protein expression
A

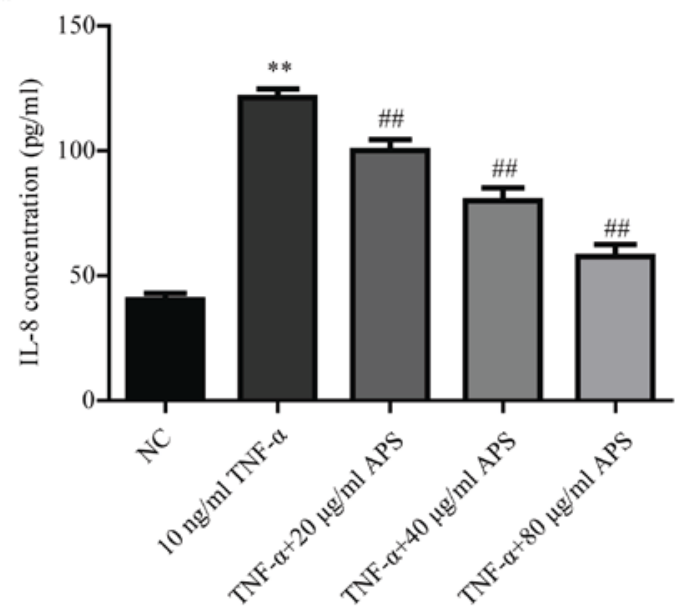

B

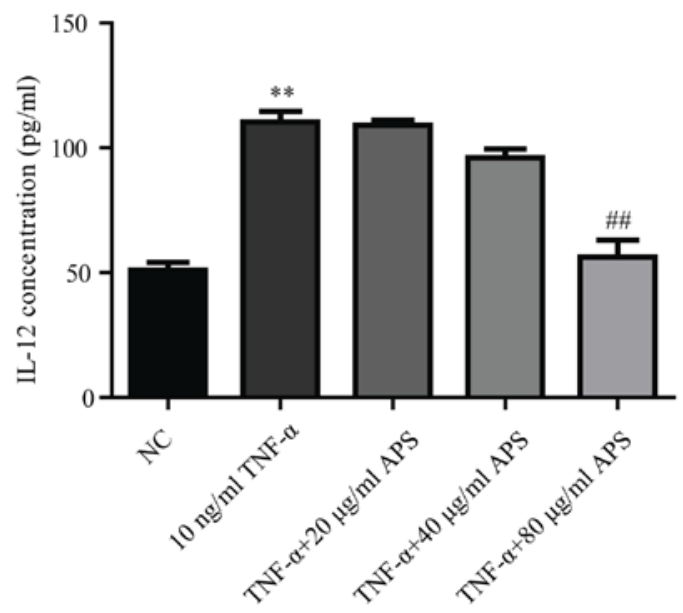

Figure 4. APS suppresses TNF- $\alpha$-induced secretion of IL-8 and IL-12 in $\mathrm{HaCaT}$ cell culture medium in a dose-dependent manner. Following treatment with TNF- $\alpha$, the expression levels of IL- 8 and IL-12 secreted by HaCaT cells into the culture medium were detected. Treatment with APS inhibited TNF- $\alpha$-induced secretion of (A) IL- 8 and (B) IL-12 into the culture medium in a dose-dependent manner. ${ }^{* *} \mathrm{P}<0.01$ vs. $\mathrm{NC} ;{ }^{\# \#} \mathrm{P}<0.01$ vs. TNF- $\alpha$-treated group. APS, aloe polysaccharide; IL, interleukin; NC, negative control; TNF- $\alpha$, tumor necrosis factor- $\alpha$.

levels of p-p65 were significantly increased in HaCaT cells compared with in the NC group; however, this effect was significantly attenuated following treatment with APS in a dose-dependent manner (Fig. 6A and B). In addition, HaCaT cells treated with TNF- $\alpha$ exhibited significantly decreased levels of I $\mathrm{B} \alpha$, an inhibitory protein of $\mathrm{NF}-\kappa \mathrm{B}$; however, this effect was significantly attenuated following treatment with APS in a dose-dependent manner (Fig. 6A and C).

\section{Discussion}

Pharmacological treatments available at present for patients with psoriasis are not satisfactory due to adverse side effects and unfavorable outcomes. Phytomedicines, including Aloe vera, indigo naturalis and Mahonia aquifolium, are therefore considered to represent alternative therapeutic approaches for the treatment of patients with psoriasis (26).

Aloe vera is a traditional medicinal agent used for the treatment of dermatological diseases. Numerous studies have 


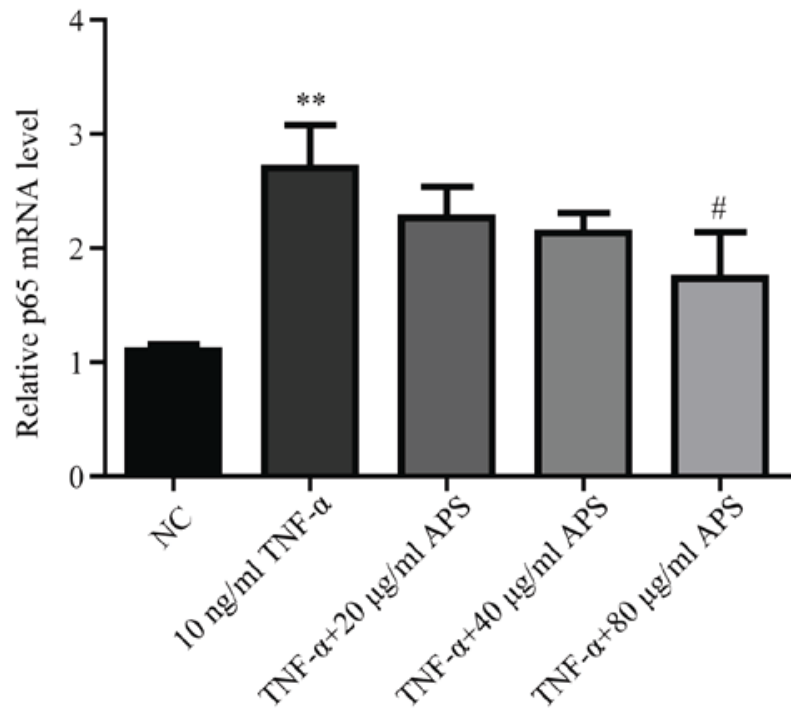

Figure 5. APS suppresses TNF- $\alpha$-induced upregulation of p65 mRNA expression. In the TNF- $\alpha$-treated group, the mRNA expression levels of p65 were significantly increased compared with in the NC group, which was significantly attenuated following treatment with APS in a dose-dependent manner. ${ }^{* *} \mathrm{P}<0.01$ vs. NC; ${ }^{*} \mathrm{P}<0.05$ vs. TNF- $\alpha$-treated group. APS, aloe polysaccharide; NC, negative control; TNF- $\alpha$, tumor necrosis factor- $\alpha$.

investigated the application of Aloe vera for the treatment of psoriasis $(6,14,15)$. Choonhakarn et al (6) revealed that Aloe vera markedly reduces the clinical symptoms exhibited by patients with psoriasis. In the present study, it was revealed that APS, the main bioactive component of Aloe vera, did not have a significant effect on the viability of HaCaT keratinocytes. However, treatment with APS was revealed to suppress TNF- $\alpha$-induced increases in $\mathrm{HaCaT}$ cell proliferation in a dose-dependent manner. These results suggested that treatment with APS inhibited excessive proliferation of keratinocytes without affecting normal skin cells.

The majority of studies that have investigated the clinical effects of Aloe vera have not determined the underlying mechanism. Dysregulation of TNF- $\alpha$ has previously been revealed to be involved in the development of psoriasis and is considered to represent a major therapeutic target (27). In the present study, it was demonstrated that APS attenuated the effects induced following treatment with TNF- $\alpha$. TNF- $\alpha$ has been revealed to induce the production of numerous cytokines, such as IL-8 and IL12, and is associated with a cytokine network involved in the pathogenesis of psoriasis (28). In addition, TNF- $\alpha$, IL-8 and IL-12 represent commonly expressed cytokines in patients with psoriasis $(29,30)$. The results of ELISA and western blotting demonstrated that $\mathrm{HaCaT}$ cells treated with APS exhibited decreased IL-8 and IL-12 expression in a dose-dependent manner, which had otherwise been induced by treatment with TNF- $\alpha$. This result is in agreement with the results of the cell viability assay, which revealed that APS was associated with proinflammatory cytokines and may suppress the proliferation of TNF- $\alpha$-treated keratinocytes in a dose-dependent manner via the suppression of TNF- $\alpha$ signaling.

It has been well established that NF- $\mathrm{KB}$ is involved in the regulation of proinflammatory gene expression via induction of the transcription of cytokines, including TNF- $\alpha$ (31). The
A

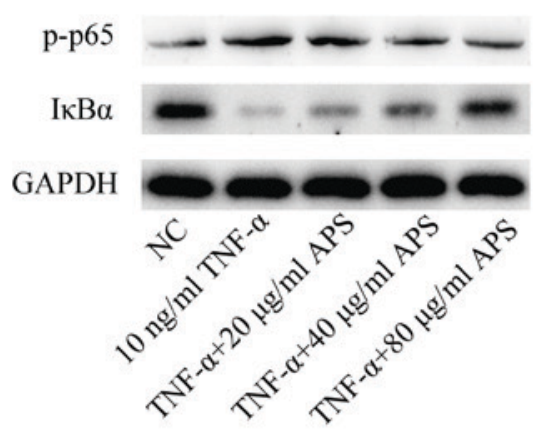

B

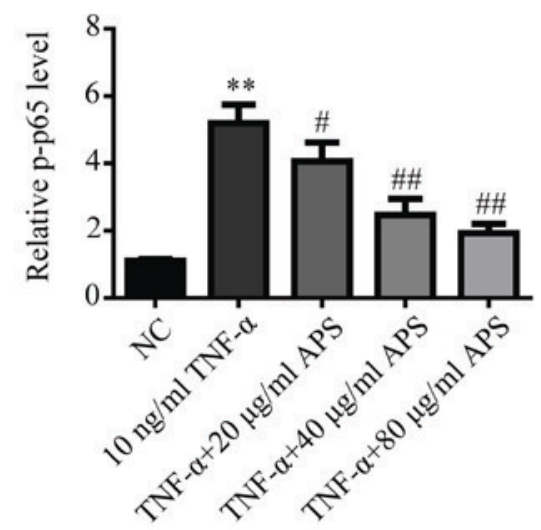

$\mathrm{C}$

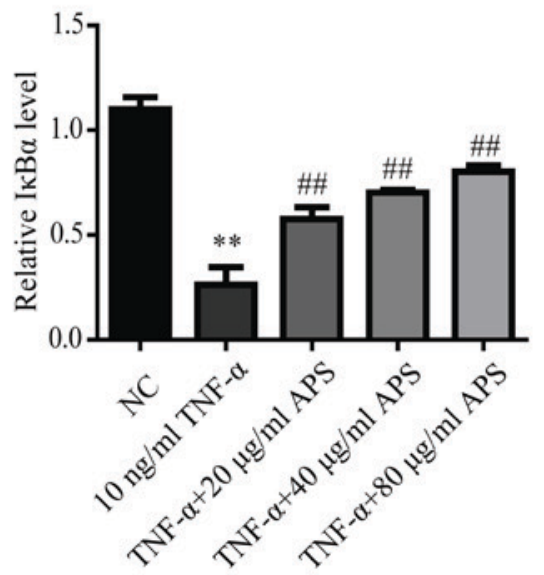

Figure 6. APS suppresses TNF- $\alpha$-induced overactivation of $\mathrm{NF}-\kappa \mathrm{B}$ activity (A and B) In TNF- $\alpha$-treated HaCaT cells, the protein expression levels of p-p65 were significantly increased compared with in the NC group, which was significantly attenuated following treatment with APS in a dose-dependent manner. (A and C) HaCaT cells treated with TNF- $\alpha$ exhibited significantly decreased I $\mathrm{B} \alpha$ protein expression compared with in the NC group, which was significantly attenuated following treatment with APS in a dose-dependent manner. ${ }^{* * *} \mathrm{P}<0.01$ vs. $\mathrm{NC}$; ${ }^{\#} \mathrm{P}<0.05$ and ${ }^{\# \#} \mathrm{P}<0.01$ vs. TNF- $\alpha$-treated group. APS, aloe polysaccharide; I $\kappa \mathrm{B} \alpha, \mathrm{NF}-\kappa \mathrm{B}$ inhibitor- $\alpha$; $\mathrm{NC}$, negative control; NF- $\kappa \mathrm{B}$, nuclear factor- $\kappa \mathrm{B}$; $\mathrm{p}-$, phosphorylated; TNF- $\alpha$, tumor necrosis factor- $\alpha$.

TNF- $\alpha$-activated NF- $\kappa \mathrm{B}$ signaling pathway is involved in inflammatory processes and forms a positive feedback loop (32). In the present study, the protein expression levels of p-p65 and the mRNA expression levels of p65 were detected. Notably, the expression levels of p-p65 in HaCaT cells were significantly increased following treatment with TNF- $\alpha$; however, treatment with APS was revealed to reverse this effect in a dose-dependent manner. Notably, p65 mRNA expression was also significantly 
decreased in response to APS in a dose-dependent manner compared with in cells treated with TNF- $\alpha$ alone. NF- $\kappa \mathrm{B}$ is sequestered in the cytoplasm by its inhibitors, such as IкB $\alpha$ and $\mathrm{I} \kappa \mathrm{B} \beta(33)$. Knockout of I $\mathrm{KB} \alpha$ in lymphocytes and keratinocytes may result in the features of psoriasis (34). In $\mathrm{HaCaT}$ cells treated with TNF- $\alpha$, the protein expression levels of IкB $\alpha$ were decreased; however, treatment with APS was revealed to attenuate this effect in a dose-dependent manner. Therefore, these results suggested that the regulation of NF- $\mathrm{\kappa B}$ activity by APS may be via enhancement of I $\mathrm{KB} \alpha$ protein expression. The results of the present study revealed that APS inhibited the NF- $\kappa B$ signaling pathway via regulation of p65 activity and p65 mRNA expression. These results provided additional information regarding the mechanism underlying the effects of APS on psoriasis treatment.

In conclusion, the results of the present study demonstrated that APS may represent a potential therapeutic agent for the treatment of patients with psoriasis. Administration of APS suppressed the proliferation of keratinocytes induced by treatment with TNF- $\alpha$. Furthermore, APS treatment NF- $\kappa B$ signaling pathways induced with TNF- $\alpha$ in proliferating keratinocytes. Therefore, the efficacy of APS administration for the treatment of patients with psoriasis appeared to rely on its anti-inflammatory activity. Based on these results, APS may be a promising drug candidate of treat psoriasis for its potential clinical applications.

\section{Acknowledgements}

Not applicable.

\section{Funding}

The present study was supported by the Natural Science Youth Foundation of Jiangsu (grant no. BK20130277), and the Jiangsu Provincial Key Laboratory of Molecular Biology for Skin Disease and STIs.

\section{Availability of data and materials}

All data generated or analyzed during this study are included in this published article.

\section{Authors' contributions}

HL and KC designed the experiments. LP, LX, XS and JJ performed the experiments. HL and $\mathrm{KC}$ wrote the main manuscript text. All authors reviewed the manuscript.

\section{Ethics approval and consent to participate}

Not applicable.

\section{Patient consent for publication}

Not applicable.

\section{Competing interests}

The authors declare that they have no competing interests.

\section{References}

1. Menter A, Gottlieb A, Feldman SR, Van Voorhees AS, Leonardi CL, Gordon KB, Lebwohl M, Koo JY, Elmets CA, Korman NJ, et al: Guidelines of care for the management of psoriasis and psoriatic arthritis: Section 1. Overview of psoriasis and guidelines of care for the treatment of psoriasis with biologics. J Am Acad Dermatol 58: 826-850, 2008.

2. Lin AM, Rubin CJ, Khandpur R, Wang JY, Riblett M, Yalavarthi S, Villanueva EC, Shah P, Kaplan MJ and Bruce AT: Mast cells and neutrophils release IL-17 through extracellular trap formation in psoriasis. J Immunol 187: 490-500, 2011.

3. Carey W, Glazer S, Gottlieb AB, Lebwohl M, Leonardi C, Menter A, Papp K, Rundle AC and Toth D: Relapse, rebound, and psoriasis adverse events: An advisory group report. J Am Acad Dermatol 54 (4 Suppl 1): S171-S181, 2006.

4. Menter A and Griffiths CE: Current and future management of psoriasis. Lancet 370: 272-284, 2007.

5. Sala M, Elaissari A and Fessi H: Advances in psoriasis physiopathology and treatments: Up to date of mechanistic insights and perspectives of novel therapies based on innovative skin drug delivery systems (ISDDS). J Control Release 239: 182-202, 2016.

6. Choonhakarn C, Busaracome P, Sripanidkulchai B and Sarakarn P: A prospective, randomized clinical trial comparing topical aloe vera with $0.1 \%$ triamcinolone acetonide in mild to moderate plaque psoriasis. J Eur Acad Dermatol Venereol 24: $168-172,2010$.

7. Das S, Mishra B, Gill K, Ashraf MS, Singh AK, Sinha M, Sharma S, Xess I, Dalal K, Singh TP and Dey S: Isolation and characterization of novel protein with anti-fungal and anti-inflammatory properties from Aloe vera leaf gel. Int J Biol Macromol 48: 38-43, 2011.

8. Davis RH, DiDonato JJ, Johnson RW and Stewart CB: Aloe vera, hydrocortisone, and sterol influence on wound tensile strength and anti-inflammation. J Am Podiatr Med Assoc 84: 614-621, 1994.

9. Baradaran A, Nasri H, Nematbakhsh M and Rafieian-Kopaei M: Antioxidant activity and preventive effect of aqueous leaf extract of Aloe Vera on gentamicin-induced nephrotoxicity in male Wistar rats. Clin Ter 165: 7-11, 2014.

10. Seyger MM, van de Kerkhof PC, van Vlijmen-Willems IM, de Bakker ES, Zwiers F and de Jong EM: The efficacy of a new topical treatment for psoriasis: Mirak. J Eur Acad Dermatol Venereol 11: 13-18, 1998

11. Paulsen E, Korsholm L and Brandrup F: A double-blind, placebo-controlled study of a commercial Aloe vera gel in the treatment of slight to moderate psoriasis vulgaris. J Eur Acad Dermatol Venereol 19: 326-331, 2005.

12. Yarilina A, Park-Min KH, Antoniv T, Hu X and Ivashkiv LB: TNF activates an IRF1-dependent autocrine loop leading to sustained expression of chemokines and STAT1-dependent type I interferon-response genes. Nat Immunol 9: 378-387, 2008.

13. Gibellini L, De Biasi S, Bianchini E, Bartolomeo R, Fabiano A, Manfredini M, Ferrari F, Albertini G, Trenti T, Nasi M, et al: Anti-TNF- $\alpha$ drugs differently affect the TNF $\alpha$-sTNFR system and monocyte subsets in patients with psoriasis. PLoS One 11: e0167757, 2016.

14. Miroddi M, Navarra M, Calapai F, Mancari F, Giofrè SV, Gangemi S and Calapai G: Review of clinical pharmacology of Aloe vera L. in the treatment of psoriasis. Phytother Res 29: 648-655, 2015.

15. Dhanabal SP, Priyanka Dwarampudi L, Muruganantham N and Vadivelan R: Evaluation of the antipsoriatic activity of Aloe vera leaf extract using mouse tail model psoriasis. Phytother Res 26: 617-619, 2012.

16. Baldwin AS Jr: The NF-kappa B and I kappa B proteins: New discoveries and insights. Annu Rev Immunol 14: 649-683, 1996.

17. Tak PP and Firestein GS: NF-kappaB: A key role in inflammatory diseases. J Clin Invest 107: 7-11, 2001.

18. Hayden MS and Ghosh S: Signaling to NF-kappaB. Genes Dev 18: 2195-2224, 2004.

19. Lizzul PF, Aphale A, Malaviya R, Sun Y, Masud S, Dombrovskiy V and Gottlieb AB: Differential expression of phosphorylated NF-kappaB/RelA in normal and psoriatic epidermis and downregulation of NF-kappaB in response to treatment with etanercept. J Invest Dermatol 124: 1275-1283, 2005.

20. Vijayalakshmi D, Dhandapani R, Jayaveni S, Jithendra PS, Rose $\mathrm{C}$ and Mandal AB: In vitro anti inflammatory activity of Aloe vera by down regulation of MMP-9 in peripheral blood mononuclear cells. J Ethnopharmacol 141: 542-546, 2012. 
21. Lima JF, Carvalho J, Pinto-Ribeiro I, Almeida C, Wengel J, Cerquera L, Figueiredo C, Oliveira $\mathrm{C}$ and Azevedo NF: Targeting miR-9 in gastric cancer cells using locked nucleic acid oligonucleotides. BMC Mol Biol 19: 6, 2018.

22. Mizuno K, Morizane S, Takiguchi $T$ and Iwatsuki K: Dexamethasone but not tacrolimus suppresses THF- $\alpha$-induced thymic stromal lymphopoitin expression in lesional keratinocytes of atopic dermatitis model. J Dermatol Sci 80: 45-53, 2015

23. Kyle S, Chandler D, Griffiths CE, Helliwell P, Lewis J, McInnes I, Oliver S, Symmons D and McHugh N; British Society for Rheumatology Standards Guidelines Audit Working Group (SGAWG): Guideline for anti-TNF-alpha therapy in psoriatic arthritis. Rheumatology (Oxford) 44: 390-397, 2005.

24. Lowes MA, Bowcock AM and Krueger JG: Pathogenesis and therapy of psoriasis. Nature 445: 866-873, 2007.

25. Yan S, Xu Z, Lou F, Zhang L, Ke F, Bai J, Liu Z, Liu J, Wang H, Zhu $\mathrm{H}$, et al: NF- $\mathrm{KB}$-induced microRNA-31 promotes epidermal hyperplasia by repressing protein phosphatase 6 in psoriasis. Nat Commun 6: 7652, 2015.

26. Deng S, May BH, Zhang AL, Lu C and Xue CC: Plant extracts for the topical management of psoriasis: A systematic review and meta-analysis. Br J Dermatol 169: 769-782, 2013.

27. Sato K, Takaishi M, Tokuoka S and Sano S: Involvement of TNF- $\alpha$ converting enzyme in the development of psoriasis-like in a mose model. PLoS One 9: e112408, 2014.
28. Gudjonsson JE, Johnston A, Sigmundsdottir $H$ and Valdimarsson H: Immunopathogenic mechanisms in psoriasis. Clin Exp Immunol 135: 1-8, 2004.

29. Sidhom E, Pilmane M and Kisis J: Local antimicrobial, protease and cy tokine defense systems in psoriatic skin. Indian J Dermatol Venereol Leprol 82: 284-291, 2016.

30. Kauffman CL, Aria N, Toichi E, McCormick TS, Cooper KD, Gottlieb AB, Everitt DE, Frederick B, Zhu Y, Graham MA, et al: A phase I study evaluating the safety, pharmacokinetics, and clinical response of a human IL-12 p40 antibody in subjects with plaque psoriasis. J Invest Dermatol 123: 1037-1044, 2004.

31. Chandel NS, Trzyna WC, McClintock DS and Schumacker PT: Role of oxidants in NF-kappa B activation and TNF-alpha gene transcription induced by hypoxia and endotoxin. J Immunol 165: 1013-1021, 2000

32. Bouwmeester $\mathrm{T}$, Bauch A, Ruffner H, Angrand PO, Bergamini G, Croughton K, Cruciat C, Eberhard D, Gagneur J, Ghidelli S, et al: A physical and functional map of the human TNF-alpha/NF-kappa B signal transduction pathway. Nat Cell Biol 6: 97-105, 2004.

33. Baeuerle PA and Henkel T: Function and activation of NF-kappa B in the immune system. Annu Rev Immunol 12: 141-179, 1994.

34. Goldminz AM, Au SC, Kim N, Gottlieb AB and Lizzul PF: NF-kappaB: An essential transcription factor in psoriasis. J Dermatol Sci 69: 89-94, 2013. 